\title{
When Globalization Discontent Turns Violent: Foreign Economic Liberalization and Internal War
}

\author{
Margit Bussmann \\ University of Konstanz \\ Gerald SCHNEIDER \\ University of Konstanz
}

\begin{abstract}
One of the disputed consequences of global economic integration is the possible effect that foreign economic liberalization exerts on social cohesion. Proponents of commercial liberalism see stabilization as an indirect consequence of growing economic interdependence, while globalization critics are much more skeptical. They expect, at least during the liberalization process, destabilizing effects. We examine in this paper the contradictory claims in the light of what we call the distributional theory of civil war. This variant of commercial liberalism qualifies the peace-throughtrade hypothesis and expects, based on political economy models of trade policy making, that the redistributive struggle associated with foreign economic liberalization can culminate in violent forms of protest. We demonstrate that a higher level of economic openness is indeed associated with a lower risk of civil war. At the same time, economic liberalization increases the chances of instability weakly. None of the following factors are found to exert any compensatory influence on instability: social spending, foreign aid, and financial flows from the International Monetary Fund. Discontent over the process of globalization is thus a destabilizing force despite the pacifying effect that the level of economic integration exerts.
\end{abstract}

One of the still unresolved globalization disputes is linked to the question of whether foreign economic liberalization increases rather than decreases the risk of civil conflict. The proponents of global economic integration typically link their optimism to the branch within the theory of economic growth that expects positive welfare gains from foreign economic liberalization (Hegre, Gleditsch, and Gissinger 2003). Sachs and Warner (1995) maintain in this vein that economic openness positively affects economic growth and social welfare. Because a potential rebel sees

\footnotetext{
Authors' note: A preliminary version of the paper was presented at the 44th annual ISA convention, Portland, OR, 2003. We would like to thank the German Foundation for Peace Research and the "Polarization and Conflict" research project (CIT-2-CT-2004-506084) funded by the European Commission-DG Research Sixth Framework Programme for financial support, J. David Singer, Erich Weede, three anonymous reviewers, and the editors for comments. Robustness checks of the results reported here as well as the data set that we used can be found on http:// www.isanet.org/data_archive.html and on the authors' replication homepage: www.uni-konstanz.de/FuF/Verwiss/ GSchneider/downloads/daten.htm
} 
the opportunity costs of political violence rising in line with the increases in personal income, societies that are economically open should be more peaceful than protectionist states.

Yet, the impact of globalization may not be as innocuous as these extensions of standard models of economic growth suggest. Some authors hold that foreign economic liberalization has destabilized fragile developing countries (e.g., Chua 2002; Brennan 2003). In the view of many globalization critics, the International Monetary Fund (IMF) as a key messenger of economic openness is among the main culprits. Stiglitz (2002:20) expects that "people riot" as a consequence of an illdesigned "international system of globalization under the aegis of the IMF." Walton and Seddon (1994:49-50) write in an early examination of the food riots that have occurred following reform attempts suggested by the global financial community: "Crowds from Rio to Rabat crying 'Out with the IMF!' demanded a restoration of food and transportation subsidies, employment, and wages commensurate with inflation."

One of the key reasons for civil unrest is, in this perspective, the redistributive effect of foreign economic liberalization and other reforms that the international financial community encourages. Our inquiry accordingly starts from the observation that, in times of growing economic ties between states, economies adjust, the export sector expands at the expense of the import-competing sector, and the income of the abundant factor increases to the detriment of the scarce factor. The potential or real losers of these reforms might try to prevent or stall liberalization measures through the usage of violence. Based on expected-utility models of civil war, we develop a theory of the distributive effects that global economic integration has on the risk of civil conflict. Our theoretical framework allows us to advance a double argument that is compatible with both the pessimism of globalization sceptics and the optimism of the proponents of economic openness. We conjecture, based on standard models of trade policy making, that the impact of the process of foreign economic liberalization (i.e., changes in economic openness) on peace can be negative, but that the effect of a higher level of integration of an economy into the world market ought to be positive. The cause of this double-sided effect is the losses that are incurred by the less productive sectors and individuals during the process of foreign economic liberalization.

The financial compensation of the losers of globalization could stop the circle of violence that foreign economic liberalization potentially unleashes. We test this compensation argument by evaluating the impact of social spending and foreign aid on the risk of conflict. Our article also examines in this context the reproach of some globalization skeptics that the harsh conditions of IMF programs destabilize the economies and societies of heavily indebted countries. We distinguish between the effects that concessional and nonconcessional IMF flows have on the risk of conflict. A negative impact of the latter sort of IMF activity would mean that the international financial community could use monetary means to pacify a state.

Economic explanations like the one that we present in this article play an important role in the study of civil conflict. Collier et al. (2003) controversially advance the thesis that the expropriation of natural resources, and thus "greed," is a key motive for armed conflict. Garfinkel, Skaperdas, and Syropoulos (2004) provide solid microfoundations to this claim, particularly showing how global economic integration can intensify the "natural resource curse." Miguel, Satyanath, and Sergenti (2004) demonstrate that economic shocks increase the risk of armed violence, while economic openness has, according to the pioneering study of Hegre, Gleditsch, and Gissinger (2003), the opposite effect. In a study of civil war in sub-Saharan Africa, Bussmann, Schneider, and Wiesehomeier (2005) lend some empirical support to the double conjecture advanced in this article that economic openness and foreign economic liberalization can have contrasting consequences. 
This article builds on these results, offering a comprehensive theoretical framework for the double conjecture and providing the most extensive tests of it so far. We first portray under which conditions measures of economic liberalization could meet domestic resistance and whether compensation can counteract the destabilizing effect of foreign economic liberalization. The research design presents the operational definitions of the main variables and introduces our method of estimation. After the presentation of the results, the article concludes with a summary and suggestions for further research.

\section{Foreign Economic Openness and Political Instability: Theory and Hypotheses}

From an individualistic perspective, the participation in a rebellion depends on the costs and benefits of violent political action. Rationalist models of civil war that have been developed independently of each other in political science and economics see in the general economic conditions of a country one of the main factors that influence the opportunity costs of war. ${ }^{1}$ It is in this vein obvious that all direct and indirect determinants of economic growth are seen as causes of peace. The policies that lead to prosperity are, however, contested as they affect some parts of the population negatively. This means that the incentives to rebel decrease for the average citizen, but that the opportunity costs for some members of society grow as a consequence of welfare-enhancing political decisions. The theory developed by us below links these double-sided effects to foreign economic liberalization and thus to one of the key components of global economic integration.

Most social scientists believe that the welfare effects of economic openness are positive. According to the neoclassical perspective, international exchange renders the division of labor between and within states more efficient. States pursuing a policy of economic openness exploit their comparative advantage and are thus enabled to produce and consume more than autarkies. If industries have to compete internationally, the prices for their goods will approach world market prices. This comes to the detriment of inefficient producers who can only survive because government interventions distort the price system in their favor, rendering the products more expensive and limiting the consumption of the population. Generations of economists have embraced the classical liberal viewpoint advanced by Ricardo (1921[1817]) that a unilateral move toward economic openness spurs growth. Sachs and Warner (1995) believe that the welfare effects of foreign economic liberalization are direct. Their cross-national comparison shows that developing countries that are economically open experience higher rates of economic growth and can better prevent balance-of-payments crises than closed economies.

One central facet of economic openness is the removal of barriers to trade. An important literature in international relations argues that trading states, to use Rosecrance's (1986) metaphor, are more pacific in their relations with other states (e.g., Russett and Oneal 2001). Hegre, Gleditsch, and Gissinger (2003) demonstrate how this key conjecture of commercial liberalism can also be extended to the domestic realm. States that trade frequently should accordingly experience fewer onsets of civil war (de Soysa 2002) and be more stable with regard to mass protests and political violence (Bussmann, Scheuthle, and Schneider 2003).

Yet, trade openness is not the only, and perhaps not even the most important, indicator of global economic integration. A further indirect effect of globalization on the risk of conflict stems, in the liberal view, from the internationalization of capital. Accordingly, countries that abolish capital controls render themselves

\footnotetext{
${ }^{1}$ The political science literature has largely dealt with the collective action problems that are linked to the decision to rebel. See Opp (1978) or Lichbach (1995) for significant contributions. The equivalent literature in economics starts with Haavelmo (1954); landmark contributions include Tullock (1974), Hirshleifer (1989), and Grossman (1991) upon which the well-known Collier-Hoeffler approach is built.
} 
attractive to foreign investors. Their financial engagement increases, in return, the capital stock of a society and, in the long run, its prospects for growth (Firebaugh 1992; de Soysa and Oneal 1999). When deciding on a location, investors take the political risk in the host country into account (Kobrin 1982). They will avoid countries in which their resources are not safe and might be threatened by looting, fighting, or expropriation if either the government or the rebels need money. Thus, states have a unilateral interest in maintaining a stable environment to attract not just trade, but also foreign investment. ${ }^{2}$ Capital account openness should thus stabilize a society at least as much as trade openness. Note that this hypothesis is in complete contrast to the dependencia school of thought which maintains that the "penetration" by foreign investment destabilizes fragile developing economies (Bornschier, Chase-Dunn, and Rubinson 1978). As these and related conjectures could not be successfully replicated (Weede 1990 for a summary), we formulate a first hypothesis that summarizes the classical liberal expectation.

Hypothesis 1: High levels of trade and foreign capital openness lessen the risk of civil war.

Even fervent proponents of global economic integration like Fischer (2003:10) support the view that one needs to distinguish between the short- and long-term consequences of economic openness: "globalization creates losers as well as winners in the short run." Along similar lines, we argue that the level and the change in economic openness need to be differentiated and examine whether the process of opening up an economy to international trade increases the risk of instability. This conjecture can be related to two classical models of international trade theory, the Ricardo-Viner model and the Heckscher-Ohlin model. According to the former approach, each sector has a factor, such as physical or human capital, specific to it in the short run. The behavioral consequence of this framework, also known as the sector-specific model, is the prediction that the conflict over foreign economic liberalization is fought along sectoral lines, most notably between the free-trading export and the protectionist import-competing industries. Within these branches of the economy, workers and employers should have similar trade policy preferences and similar incentives to use force. Moves toward economic openness diminish the opportunity costs of political violence for employers and workers within the importcompeting industry. The contrary is the case for the export sector in which both capitalists and workers profit from increasing economic openness.

The Heckscher-Ohlin model sees a division between factors or classes as the key feature of trade policy making. The model, also dubbed the factor proportions model, is more general than the Ricardo-Viner model, as it abandons the assumption of sector specificity. It predicts that the abundant factor favors free trade, while the scarce factor pushes for protectionist measures. In the industrialized world, labor would lose under foreign economic liberalization and capital would win. As capital is scarce and labor abundant in developing countries, the cleavage would take the opposite direction in these states. ${ }^{3}$

Explanations that stress the redistributive effects of trade policy liberalization are particularly appropriate for the developing world in which the government most often is weak. Before the "rush to free trade" (Rodrik 1994) started in the 1980s, most of these states were protectionist (Martin 2005). The political economy of developing countries was thus largely determined by state regulation and rentseeking, both aiming at the enrichment of the ruling elite and the stability of the

\footnotetext{
${ }^{2}$ Studies examining the relationship between foreign investment and internal conflict are inconclusive; some reveal no relationship (Bollen and Jones 1982; Crenshaw 1991), whereas others find internal conflict to reduce FDI (Chan and Mason 1992; Resnick 2001).

${ }^{3}$ Rogowski (1989) provides, based on the related Stolper-Samuelson Theorem, a widely acknowledged account of how we can conceptualize this dispute in a political setting.
} 
regime, rather than the welfare of the population (Tullock 1980; Weede 1990). In such economies governments use the income from foreign exchange and tariffs to garner the political support from the import-substituting industries. Although these industries are often managed uneconomically by followers of the government, neither the government nor the elites have an incentive to make them more competitive. As a consequence the national economy suffers and reforms become inevitable.

Foreign economic liberalization destabilizes the existing social system because the profiteers of a closed economy lose a large share of income. Rodrik (1994) estimates that the cost-benefit ratio of foreign economic liberalization is larger than five; this means that for each unit of additional income from liberalization, five units will be redistributed, rendering reforms extremely difficult. Another problem of foreign economic liberalization results from power disparity between the winners and losers of reform. The general public is certainly among the profiteers. However, the individual benefit of group members is minuscule. Conversely, the losers are a small group, which contains parts of the political elite, for which the stakes of liberalization are very large. An additional obstacle to large-scale liberalization results from the impossibility for protectionists to garner rents after the reform. This source of income dries up completely through liberalization, while the welfare gains materialize only gradually.

The plan to liberalize an economy makes states thus susceptible to political instability. On the one hand, the government has to improve the economic situation in order to avoid turmoil in the population and to weaken the opposition. On the other hand, the government is afraid that the protectionist elites will launch a coup in order to prevent or reverse reforms. As Alesina and Drazen (1991) and Hsieh (2000) have shown, the fight of competing political groups often delays necessary political reforms. We adopt a similar argument and show how the use of force can be associated with plans by the governing elites and international financial institutions to open up an economy to foreign competition. In our framework, foreign economic liberalization decreases the opportunity costs of civil unrest for losers of foreign economic liberalization. Their uncertainty over the effects of reform renders the status quo attractive for much longer than what is in their own interest (Fernandez and Rodrik 1991). Political violence becomes a possible course of action as long as the long-term growth effect of foreign economic liberalization does not offset the short-term costs of adjustment that the losers of globalization have to bear. As it is the case with the support for political reforms, the likelihood of civil peace will thus follow a J-curve during the transformation process (Hellman 1998).

Our argumentation thus far suggests how changing trade openness affects the income of competing social groups and, in our extension, their opportunity costs for using force. Similar effects can be expected from changes in the level of capitalaccount openness and the inflow of foreign direct investment (FDI). The inflow of long-term FDI can involve either the complete take-over of an existing enterprise, the foreign firm becoming a controlling shareholder, or simply the buildup of new production sites. With the initial engagement of a foreign investor, we can expect a jump in inflowing foreign investment and thus a higher growth rate of FDI inflows. It is during the phase of the initial engagement when we expect to observe protests of the losers of this transaction in the host country. In the case of a company takeover, protests are likely to arise from current managers and local employees that might be replaced due to potential restructuring. If foreign investment is used to set up a new factory, where new jobs are created, we still might see opposition from local businesses that fear the new competition.

It is also possible, however, that the growth rate of investment inflows is negative. In this case, we might not find less instability but protests from different losers, this time from the ones that lose their jobs or privileges from reduced FDI inflows. A similar rationale applies to changes in trade openness. Hence, we do not claim 
that changes toward globalization are exclusively linked to increased instability. Rather, we argue that both moves toward protectionism and toward increased levels of economic interaction carry the seed of frustration and violence.

Whereas our study analyzes the effect of inflowing production capital and its change in general, globalization skeptics frequently focus on the adverse impact of short-term investment. In a trenchant critique of an IMF paper, Stiglitz (2004:63) expects the effects of short-term financial flows to be destabilizing. His models depart from neo-classical accounts of openness and show how "capital market liberalization exposes a country to new shocks, and weakens the built-in shock absorbers in the economy, provided by the price system." Countries that have received much short-term investment during the boom period will lose the confidence of the international financial community in a situation of quickly deteriorating economic conditions and fall victim to speculative attacks.

The impact that long-term investment has on the economy, in contrast to shortterm financial flows, is expected to be positive. Note, however, that empirical studies will not necessarily exhibit these countervailing influences. As Stiglitz (2004) maintains, aggregate analyses of the effect of investment on economic growth often encounter that the influences of the two forms of international exchange cancel each other out.

Hypothesis 2: Positive and negative growth in the level of trade and foreign capital openness increases the risk of civil war.

The compensation of the losers of foreign economic liberalization could be used as a means to reduce the risk of war. If the winners do not voluntarily pay off the potentially bereaved, the state might step in to help threatened sectors and factor owners to deal with the adversities of globalization. As Rodrik (1998) has revealed, the size of government positively correlates with trade. Garrett (2001) has similarly demonstrated that increasing capital mobility does not reduce government spending in a large sample, while Quinn (1997) showed that the tax base does not have to shrink as a consequence of growing globalization. Other studies have, however, exhibited that the relationship between openness and state capacity is far from being clear-cut. Rudra (2002) demonstrates, for instance, that globalization has diminished social spending exactly in the states where the power of labor is weak. Azam (2001), moreover, has argued that social redistribution only works under the condition that a government can credibly commit itself to a redistributive mechanism; this is frequently not the case in the developing world, where compensation beyond ethnic allegiances is unlikely. A further problem is that compensation is not individually rational for the winners of globalization. Although all competing groups lose from hostilities during a period of economic adjustment, they might want the other side to bear the costs of reform. The resulting "war of attrition" delays, as indicated, the implementation of welfare-improving measures (Alesina and Drazen 1991).

We will nevertheless examine against this skeptical backdrop whether compensation reduces the risk of conflict. Attributing this process not the least to globalization, Rudra $(2002,2004)$ has presented encompassing evidence that welfare spending has declined in the developing world. Whether this has contributed to the surge in the number of armed conflicts needs to be seen.

Compensation can also originate from foreign aid and non-conditional lending, which we differentiate here from conditional lending. International financial flows are especially, then, a relevant source for compensation when the government does not have sufficient resources at its disposal. With the help of foreign aid and nonconcessional flows from the international financial community, the government can gather the money it needs to compensate losers of liberalization. Conversely, conditional lending - and especially the type done by the IMF — is frequently said to be 
destabilizing in developing countries (e.g., Walton and Ragin 1990). The structural adjustment programs that the Bretton Woods institutions link to their lending activities typically include not only conditions such as privatization, reducing trade barriers, measures to attract more foreign investment, and currency devaluations, but also measures that aim at reducing public spending, all conditions that have various distributional aspects. Empirical studies on how lending or foreign aid relate to the conflict propensity of states are rare. While Bussmann, Schneider, and Wiesehomeier (2005) cannot show for sub-Saharan Africa a robust impact of conditional lending by the IMF on the risk of conflict, Collier and Hoeffler (2002) demonstrate that aid reduces the conflict propensity of a state only indirectly through increased growth. Although the quality of the data on IMF lending is limited, we will nevertheless examine whether compensatory measures by the international community or the state are in any way related to the risk of conflict.

Hypothesis 3: Compensating the losers of foreign economic liberalization through increased social spending or foreign aid reduces the risk of civil war, while conditional lending increases the risk of conflict.

\section{Research Design}

We examine the hypotheses of a relationship between the onset of civil war and foreign economic openness and liberalization with data for 127 developed and developing countries for the time period from 1950 to 2000. As the onset of a civil war is a dichotomous event, we will utilize a pooled time-series cross-section logit model with robust estimation of variance. ${ }^{4}$ This method allows the researcher to gauge the probability that an event occurs (i.e., the probability that the dependent variable takes the value one). Simultaneously we control for dynamic effects and some of the heterogeneity unaccounted for by the explanatory factors.

\section{Description of Variables}

Onset of Civil War - For our dependent variable we use the data set on armed conflict released jointly by the Conflict Data Project at Uppsala University and the Peace Research Institute in Oslo (Gleditsch et al. 2002). We chose the lowest conflict threshold of 25 battle-related deaths in order to include as many armed conflicts as possible, as we are interested in unrests that are politically significant, without necessarily having to use a data set with a higher casualty threshold. ${ }^{5}$ We concentrate on internal armed conflict and internationalized internal armed conflict and restrict our analyses to conflicts that occur in the country of reference. The dichotomous variable for the onset of armed conflict takes the value of one if a civil war started in a given year and zero otherwise. Subsequent years during which a country was

\footnotetext{
${ }^{4}$ We estimated a random-effects, a fixed-effects, and a population-averaged model in addition to the pooled model that we presented. All variables keep their expected signs and significance in the random-effects and the population-averaged models. In the fixed-effects model some of the control variables become insignificant, namely economic development and growth. However, our results are robust for the openness and liberalization variables. The $\rho$ in the panel estimation was very small and statistically not significant, indicating that estimation with a pooled model is sufficient.

${ }^{5}$ The dataset on armed conflicts distinguishes between minor armed conflict (at least 25 battle-related deaths/ year but fewer than 1,000 during the whole conflict), intermediate armed conflict (more than 25 casualties/year and more than 1,000 in total), and war (more than 1,000 casualties/year). We conduct robustness tests on these various specifications of civil war.
} 
involved in the conflict were dropped from the sample. Once the civil war has ended, the country enters the sample again. ${ }^{6}$

Measures of Openness and Liberalization - As economic globalization is a multifaceted process, we distinguish between regulatory and outcome measures of global economic integration. To start with the latter concept, our statistical analysis uses four outcome measures as independent variables: trade openness, trade liberalization, foreign capital openness, and foreign capital liberalization. The openness variables account for the level of economic integration (Hypothesis 1) and the liberalization variables stand for the changes in the level of openness (Hypothesis 2). In other words, we differentiate between economic openness (i.e., the extent to which the state is actually integrated into the world economy) and economic liberalization (i.e., the process through which the government liberalizes its economy). Obviously, the two concepts are hard to distinguish in the long run, as the level of openness variable represents the sum of all changes over time. Nevertheless, the differentiation between "openness" and "liberalization" is useful because we are interested in the impact of short-term and long-term manifestations of globalization.

For trade openness we rely on a customary measure that calculates the sum of exports and imports divided by GDP using data from the Penn World Tables, version 6.1 (Heston, Summers, and Aten 2002). To capture the effects of trade liberalization, we use the yearly growth rate of the trade-to-GDP measure of openness. As we expect both a move toward and away from free trade to have a destabilizing effect, we distinguish between positive and negative growth rates. Therefore, we create a variable accounting for liberalization that equals the growth rate of trade openness if the growth rate is larger than zero; negative values are set to zero. Equivalently, the variable for a move away from free trade takes the negative values of growth in trade openness and replaces the positives values with zero.

We analyze the effect of FDI with data from the UNCTAD (2002) foreign direct investment database. The focus is on foreign-investment inflows in relation to GDP as the indicator of the level of foreign capital openness and, similar to the measure devised for trade openness, we use its positive growth rate as a measure for the liberalization of foreign-capital inflows. The UNCTAD data is a compilation of data from various sources, such as the IMF and the World Bank, but still has a great number of missing observations. In order to avoid list-wise deletion, we linearly interpolated the data within the time series.

A problem with these outcome measurements is that trade and investment do not necessarily provide sufficient information about the policy aspects of openness and liberalization (Martin 2005; Martin and Schneider 2007). ${ }^{7}$ Outcome measures can be misleading because a high trade-through-GDP ratio and growing foreign investment do not measure the policy process, but rather reflect economic and geographic attributes of a country; multivariate models will only imperfectly take this measurement problem into account. For this reason we will look at regulatory measures of economic integration with the CACAO indicator developed by Martin (2005). This indicator measures the regulatory hurdles that hinder the exchange of goods and capital on an ordinal scale from zero to seven. The advantage of this dataset is that it considers the policies that are relevant for liberalizing the domestic economy. Regulation results from domestic decision making and represents the

\footnotetext{
${ }^{6}$ If the outbreak of a recurring civil war largely depends on the characteristics of the previous war, this might be problematic. However, Walter (2004) found in her study that high levels of economic well-being and a citizen's access to political participation are important factors, regardless of what has happened in a previous conflict. In addition, we do to some extent account for the countries' history through the usage of the peace-years correction.

${ }^{7}$ Foreign economic liberalization signifies the withdrawal of regulative obstacles for free trade and for the movement of capital across borders.
} 
actual balance of power. This is exactly the point in time where we expect most conflict. Owing to the ordinal character of the measure, we use a value of one if liberalization took place and zero if not. We also include a dummy variable indicating if a country became more restrictive. The CACAO indicator, which is based on the quantitative content analysis of the IMF's annual publication "Report on exchange arrangement and exchange restrictions," is available only since $1980{ }^{8}$

Measures of Compensation and Lending - We use various indicators to examine the prospect that the financial compensation of the losers of globalization can mitigate the destabilizing effect of liberalization. As we are unable to quantify the demand for compensatory payments, we focus on the supply side. Our first indicator, general government consumption as a percent of GDP, accordingly measures the distributional capacity of the state. As compensation can also originate from international resources, we analyzed the impact of financial flows from the international community. Specifically, we examined the impact of foreign aid, including net official development assistance as well as concessional and nonconcessional IMF flows. All measures are set in relation to a country's GDP. The source for the measures of compensation and lending is the World Bank's World Development Indicators (2004).

\section{Control Variables}

Whereas our focus is on the relationship between economic liberalization or openness and political violence, we control for other factors that have been argued in previous literature to be potential causes of instability and have also been found to be robust in a sensitivity analysis (Hegre and Sambanis 2006). Most of these controls consider, in line with our general argument, the opportunity costs of violence.

Economic Development and Growth-The conjecture that links economic development and growth to political stability has, starting with Lipset (1959), a distinguished idea history in political science. Most recently, Collier and Hoeffler $(1998,2004)$ offer an opportunity cost version of this explanation. ${ }^{9}$ We added the GDP per capita in logarithmic form as a control variable to our regression, taken from the Penn World Tables (Heston, Summers, and Aten 2002), and economic growth is measured as the yearly growth rate of GDP per capita.

Democracy - The relationship between democracy and internal political violence, as some studies suggest, follows an inverse U-curved relationship (e.g., Hegre et al. 2001). We operationalized the type of regime with the widely used Polity IV index (Marshall and Jaggers 2000), ${ }^{10}$ which we use in its simple, as well in a squared, form to examine whether the relationship is curvilinear.

Population - Large states are more susceptible to conflict because they are more heterogeneous, which increases the probability that individual groups expect an advantage from secession, a relationship that is confirmed in the literature (e.g., Rothgeb 1990; Collier and Hoeffler 1998). More importantly, the variable needs to be added to the model in order to avoid the potential problem that the openness

\footnotetext{
8 The "Report on Exchange Arrangement and Exchange Restrictions" has been published annually since 1979 by the International Monetary Fund. It contains information on member states' current and capital account policies as well as information about exchange practices. Although the composition of individual country reports has changed over time, it is the most systematic source available to date on the regulatory aspects of foreign economic liberalization for a broad range of countries. CACAO consists of a number of dummy variables that capture various aspects of trade, exchange and capital account policies. We rely on the measures that Martin (2005) has developed.

${ }^{9}$ Fearon and Laitin (2003) use per-capita income as an indicator for the strength of the state.

${ }^{10}$ We added 11 points to each value so that we have a regime score ranging from 1 to 21.
} 
measures are indirectly accounting for the size of a country. Large countries are less strongly integrated into the world economy because they can satisfy the need of the population within the domestic market, whereas for small states, integration in the world economy gives access to a larger market (Alesina and Wacziarg 1998). We use a logarithmic transformation of this indicator and rely on the World Bank (2004) as a data source.

Civil War in Neighborhood - The spatial correlation of our data poses a problem. There are risks of civil war spillover between neighboring countries. Refugee flows and rebels hiding across the border can destabilize the host country. In addition, there are negative economic spillovers from civil wars, such as regional arms races, hampered reputations for investors, and lower economic growth rates also in the neighboring states, factors that can in turn increase the risk of instability (Collier et al. 2003). As we want to directly measure geographic dependencies, we add a dummy variable for whether a civil war took place in countries that are directly contiguous.

Peace Years - As discussed by Collier and Hoeffler (2004), the length of the period of peace is an important control variable that accounts for both the gradual depreciation of armament and military training as well as declining grievances resulting from the last conflict. Besides its theoretical importance, this variable is a control for temporal dependence (Beck, Katz, and Tucker 1998). The period of peace is calculated as the number of years since the last conflict, using the program BTSCS Data Analysis Utility, Version 4.0.4 (Tucker 1999), and we include it together with three splines in our model.

For the variables economic development, civil war in the neighborhood, democracy, openness, liberalization, and the measures of compensation, we take the values from the previous year in order to avoid the endogeneity problem that the variables are influenced by civil war. Table 1 summarizes our basic model, indicates the signs that we expect for the independent variables, and lists the operational definitions of these concepts.

\section{Results}

This article advances in line with the distributional variant of commercial liberalism the double claim that the level of economic openness pacifies societies, while changes in this level increase the risk of civil war. In multivariate regression analyses, presented in Table 2, we examine the relationship between openness, liberalization, and instability while holding other influences constant.

The first model shows the effects of the level of trade openness and of trade liberalization on the outbreak of a civil war. The coefficient of openness is negatively related to onset $(p<.05)$, which supports our hypothesis that countries that are integrated into the world economy are more peaceful. The liberalization variable (the positive growth of trade openness) measuring the effects of the process of opening an economy has the expected positive sign and is highly significant. ${ }^{11}$ A negative growth rate of openness (i.e., a move away from trade) is statistically not significant. ${ }^{12}$ In results not reported here, we also tested the level of openness and its growth rate lagged by three, five, or ten years. Trade openness is still significant and negatively related to the onset of civil war, but growth in openness is not when lagged. This shows that the level of openness is a pacifying force in the long run and the change in openness destabilizes only in the short run. Hence, we have some first

\footnotetext{
${ }^{11}$ Our results hold up if we use the yearly change in trade openness not as growth rate but as first difference.

${ }^{12}$ We did not include the negative growth rate variable, or any of its operational variations, in further tests, as it was insignificant in all specifications.
} 
TABLE 1. Expected Influence of Different Variables on the Onset of Civil War

\begin{tabular}{|c|c|c|}
\hline Independent Variables & $\begin{array}{c}\text { Expected Influence } \\
\text { on Civil War } \\
\text { Onset }\end{array}$ & Operationalization \\
\hline Trade openness $t-1$ & - & (Exports + imports)/GDP \\
\hline Positive growth in trade openness $t_{t-1}$ & + & $\begin{array}{l}\text { Yearly growth rate of trade openness if } \\
>0 ; 0 \text { otherwise }\end{array}$ \\
\hline Negative growth in trade openness $t_{t-1}$ & + & $\begin{array}{l}\text { Yearly negative growth rate of trade } \\
\text { openness if }<0 ; 0 \text { otherwise }\end{array}$ \\
\hline $\begin{array}{l}\text { Liberalization in regulatory trade } \\
\text { openness } \\
t-1\end{array}$ & + & 1 for liberalization, 0 otherwise \\
\hline FDI openness $t-1$ & - & FDI inflows/GDP \\
\hline Government consumption $_{t-1}$ & - & General government consumption/GDP \\
\hline Growth in government consumption ${ }_{t-1}$ & - & $\begin{array}{l}\text { Yearly growth rate in government } \\
\text { consumption }\end{array}$ \\
\hline Concessional IMF flows $t_{t-1}$ & + & Concessional IMF flows/GDP \\
\hline Non-concessional IMF flows $t-1$ & - & Non-concessional IMF flows/GDP \\
\hline Official development assistance $_{t-1}$ & - & Official development assistance/GDP \\
\hline Level of development $t_{-1}$ & - & Log (GDP per capita) \\
\hline Democracy $_{t-1}$ & + & Autoc-Democ +11 \\
\hline Democracy squared $_{t-1}$ & - & $(\text { Autoc-Democ }+11)^{2}$ \\
\hline Population & + & Log (population) \\
\hline Economic growth & - & Yearly growth rate of GDP per capita \\
\hline Civil war in neighborhood $t-1$ & + & Dummy variable \\
\hline Peace years & - & Number of years since last conflict \\
\hline
\end{tabular}

support for our proposition that commercial liberalism needs to be rectified in its application to domestic politics.

The signs for the control variables point in the expected directions. For democracy, we find confirmation that the relationship has the shape of an inverted $\mathrm{U}$-curve; the squared term is negative and the simple term positive. In autocracies and democracies the danger of civil war does not loom as large, whereas in semiautocratic regimes the risk of experiencing political violence is higher. The inflection point is at 1.29 of the Polity scale, which means that up to this value, the risk of civil war increases, and after this point democratization reduces the likelihood that a civil war breaks out. ${ }^{13}$ Economic development is negatively related to the onset of civil war, a significant result that supports previous findings of poverty as a main cause of political violence. Economic growth reduces the danger of an onset. In populous states there is a higher risk of civil war onset; remember we keep this variable in the model due to its importance as a control for the size of the domestic market. The dummy variable controlling for whether a civil war took place in a neighboring country also positively influences the outbreak of a civil war. The peace-years variable that corrects for the temporal dependence is, together with its three splines, jointly significant.

In the second column, we use the regulatory indicator for trade liberalization, which is more policy-oriented than the outcome variable measuring the growth in the trade/GDP ratio. ${ }^{14}$ The coefficient for this indicator of trade liberalization is

\footnotetext{
${ }^{13}$ Based on the results reported in the first column of Table 2, we calculated the inflection point as $-0.2041 /$ $\left(2^{*}-0.0083\right)$ that equals 12.29 . From this number we subtracted 11 points to return to the original Polity IV scale and thus have a value of 1.29 .

${ }^{14}$ For this and the following test we had to limit our time frame due to data availability of the new variables. We repeated the previous tests for the shorter time frame and find that the results persist.
} 


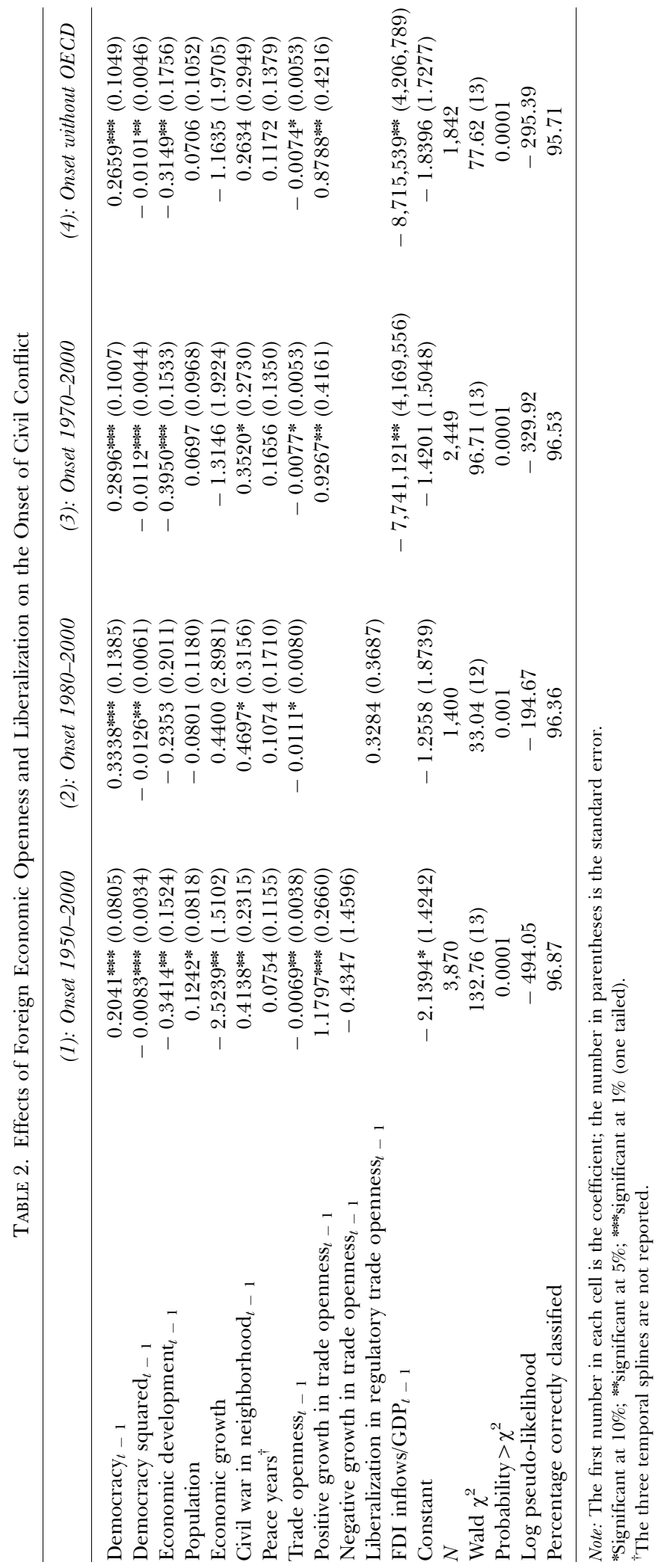


again positive, but the result is statistically not significant. The level of trade openness remains a pacifying force. In the third model, we do not find support for a destabilizing effect of FDI. The inflow of foreign capital significantly reduces the risk of civil war. ${ }^{15}$ With the inclusion of the FDI inflow variable alongside the trade openness measures, we see that the coefficient and the level of significance of trade openness $(p<.08)$ decline somewhat, but this variable still remains significant. Thus trade openness and FDI inflows are complementary influences for peace. The effect of trade liberalization (growth in trade openness) continues to be a significant destabilizing factor.

Finally, in the last column, we excluded the OECD countries from the sample to ensure that our results are not distorted by the industrialized states that are presumably at lower risk of experiencing a civil war. A country might need a certain level of development to fully exhaust the peaceful benefits of openness. It is equally possible that only countries that have reached a certain level of development are able to compensate the losers of foreign economic liberalization. Rodrik (1998) and others have pointed out at the theoretical level that globalization works best in states with an active welfare policy. The results of the level and the growth rate of trade openness are robust for the different samples.

In Table 3, we analyze the distributional aspect of our argument more directly. First, we evaluated the effect of income inequality with the Gini index as a proxy for the demand side of distributive measures with data from Deininger and Squire (1996). ${ }^{16}$ Presumably states with a very unequal income distribution (i.e., a high Gini coefficient) are more prone to experience a conflict. However, the Gini index is statistically not significant (see column 1). This is consistent with Fearon and Laitin's (2003) findings. The level of trade openness remains negatively, and the growth in trade openness positively, related to conflict onset. Owing to the quality of the data on income distribution and to the small sample size, we need to be cautious when drawing general conclusions. ${ }^{17}$

Based on the supply side of redistribution, we looked at the size of the government to evaluate whether a state has the resources to compensate the losers of globalization. Other variables in our model, economic development and economic growth, also serve as proxies for state capacity (Fearon and Laitin 2003) and the state's ability to redistribute. However, government consumption as percent of GDP and its growth rate more directly assess the distributional means. In column 2 we see that the variables on government consumption are not significant, and their inclusion had no effect on our openness and liberalization variables. ${ }^{18}$ In column 3 , unlike expected, it is the net flow of nonconcessional IMF money that is positively related to conflict onset. Concessional IMF flows are statistically not significant. ${ }^{19}$ In the last model, the variable for official development assistance also has no effect. The openness and liberalization variables

\footnotetext{
${ }^{15}$ We also tested equivalently to trade openness the positive and negative growth rate of FDI inflows and the effect of the more policy-oriented measure of liberalization, the liberalization in regulatory capital openness, which were statistically not significant.

${ }^{16}$ We use the data as prepared in Bussmann, de Soysa, and Oneal (2005), who only included observations in the data set that meet the high quality standards of data collection and who also corrected them for various characteristics of the surveys according to a method by Dollar and Kraay (2002).

${ }^{17}$ In order to increase the number of observations, we estimated an interpolated version of the Gini index, which we additionally extended in case of missing values by using the last reported value for the following and previous years in a time series. Without extending the data, we have an extensive drop in observations and the Gini variable is insignificant, as are some of the other independent variables. In particular, our variables for economic openness and liberalization are no longer significant due to the small sample size.

18 The two variables are correlated at $r=.14$. If included separately in the equation, the results remain the same. Government consumption includes compensation of employees but also most expenditure on national defence and security. As we are interested in the effect of compensation a government pays, we ran tests where we hold military expenditures (with data from the national capability data set of the Correlates of War project) as a fraction of GDP constant. Government consumption was still statistically not significant.

${ }^{19}$ If entered separately in the equation, both variables show similar results.
} 


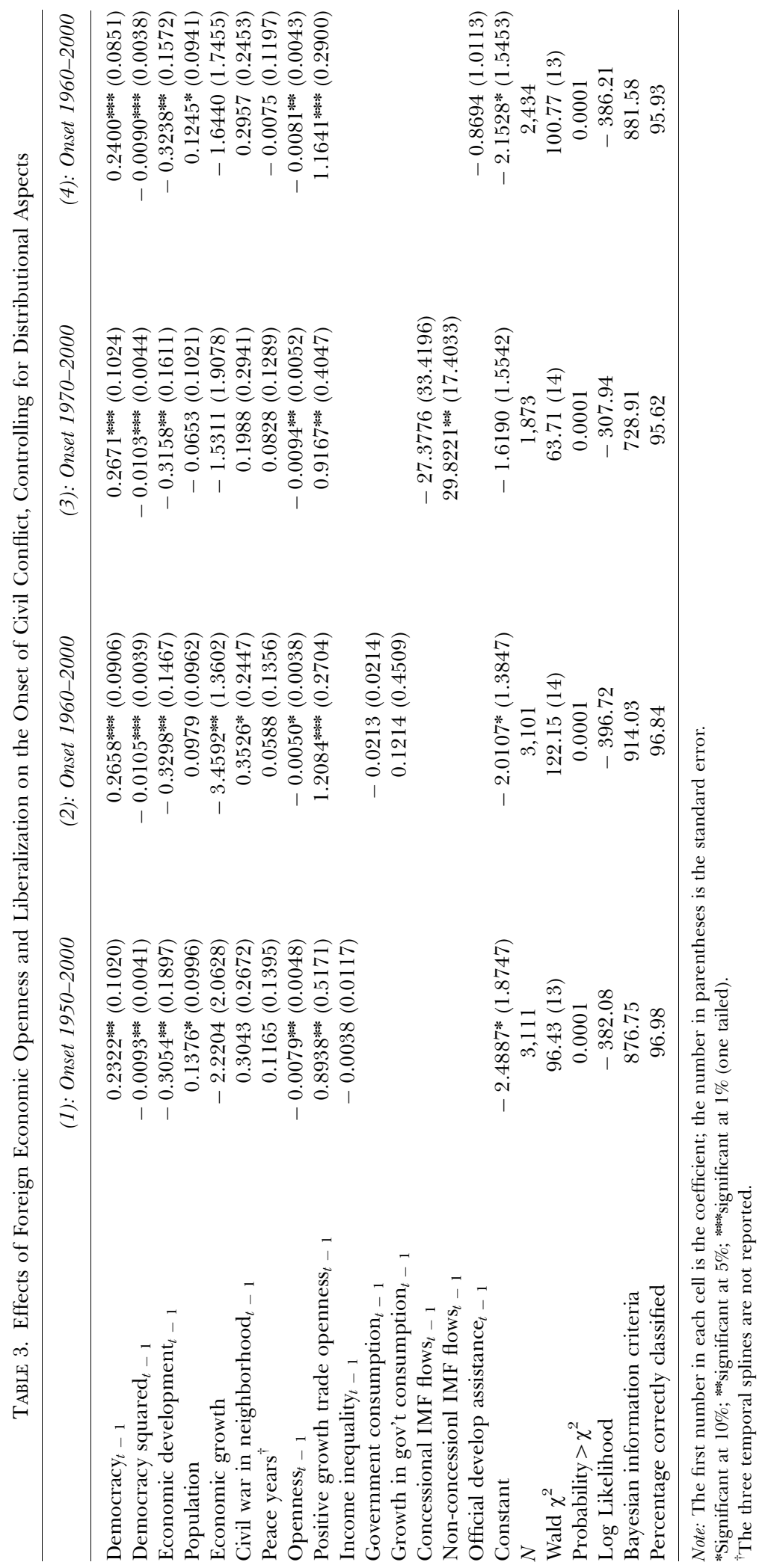


still have their respective signs. Thus, holding various sources of compensation payments constant, foreign economic liberalization still exerts a destabilizing effect. As various robustness checks show, the impact of global economic integration on the short-term risk of civil war remains significant across various specifications. ${ }^{20}$

Next, we explore the substantive importance of the results by taking a closer look at the magnitude of the various effects. If we base our predictions on Model 3 in Table 2 and use version 2.1 of the software package Clarify (King, Tomz, and Wittenberg 2000; Tomz, Wittenberg, and King 2003), the risk that a conflict breaks out amounts to 1.66 percent. This calculation is referring to a hypothetical baseline case where all variables are at their mean and none of the neighboring countries are at war. Other things being equal, if we change the value of trade openness from its 25 th to 75 th percentile, that is from 41 to 82 , the probability of civil war onset declines by -0.0052 (with a standard error of 0.0038 ). In relation to the baseline probability, this is a reduction of 31 percent. Similarly, if the inflow of FDI increases from the value of the 25 th to 75 th percentile, the probability of onset declines by -0.0023 (with standard error equal to 0.0014 ), a reduction of 13.8 percent from the baseline. Having the growth rate of trade openness increase by 7 percentage points (from the 25th to 75 th percentile) leads to a higher risk of an outbreak of armed conflict by 0.0011 (with a standard error of 0.0006 ), which is an increase of 6.6 percent from the baseline risk. However, if we take into account that growth in openness increases at the same time as the level of openness (e.g., a growth in trade openness of 10 percent changes the level from a mean of about 67 to a mean of 73.7), the probability of an onset increases by 0.00073 (standard error equal to 0.00096 ), which is only an increase of 4.4 percent from the baseline probability. ${ }^{21}$ Whereas the substantive risk of conflict onset in the wake of foreign economic liberalization is not very high, the conflict-reducing effect of economic openness is quite substantial, especially if compared with a respective increase in real GDP per capita, which would reduce the likelihood of onset by 75 percent (from the baseline probability).

The marginal effects imply that the destabilizing impact of trade liberalization is not very strong, especially considering the small predictive power of the overall model. Whereas our models correctly classify more than 95 percent of the observations, this number can be misleading. The model without the liberalization variable only predicts peaceful outcomes, which is true for the large majority of cases; thus, we have a high percentage of correctly predicted outcomes. With liberalization included, the model at least correctly predicts three civil war onsets and no single peace year was predicted falsely as an onset. The three onsets that were correctly predicted are the same cases that showed up in an outlier analysis. In the outlier analysis we assessed whether our results are influenced by extremely large values of openness and growth in openness. The results were robust with regard to trade openness but not for the growth rate of openness. ${ }^{22}$ This indicates that, in line with the theoretical argument advanced by the distributional variant of commercial

\footnotetext{
${ }^{20}$ See the discussion of the robustness tests on the web appendix.

${ }^{21}$ The probability of onset does not vary much if we start with different levels of openness. If we start from an openness value at its 25 th or 75 th percentile instead of the mean value of openness, the increase in onset probability is then 7 or 3 percent if openness grows by 10 percent.

${ }^{22}$ Based on the first model in Table 2, we dropped the five largest, or respectively the five smallest, values successively or individually. The results were robust; trade openness continues to be negatively related to the onset of conflict. This holds even with lower omission thresholds. The results were not robust with regard to the growth in trade openness. The omission of some of the largest values individually reduces the significance level to $p<.05$, and when we drop the observations with the three largest values together, Zaire in 1964, Indonesia in 1967, and Russia in 1993 , the significance level declines to $p<.38$ and the coefficient drops to 0.437 . The conflict in Zaire was related to the vacuum in political power that the Belgians left behind, Indonesia was involved in a dispute over West Papua and its independence movement, and in Russia there was a coup attempt in 1993. Exactly how the economic liberalization in the three cases contributed to the instability needs to be investigated in a carefully conducted case study.
} 
liberalism, an extremely fast growth rate in trade openness increases the chances that a conflict breaks out, whereas moderate and slow liberalization is less destabilizing.

To sum up, we can conclude from the tests that in the long term an open economy is related to less conflict. The coefficient continuously has a negative sign. Furthermore, the inflow of foreign capital has a pacifying impact. However, the process of trade liberalization bears the risk of civil-war onset if extreme cases of liberalization are included in the sample. Although the support for the globalization-skeptical hypothesis is not as strong and robust as the distributional variant of commercial liberalism makes us believe, we would like to stress that the supposed relationship holds more strongly in the subsample of sub-Saharan African states than in the global sample under examination here (Bussmann, Schneider, and Wiesehomeier 2005). We believe that this divergence is a result of the impossibility in many African states to protest in a nonviolent manner against plans to liberalize the economy, while citizens in other countries can resort to other instruments to show their discontent. Moreover, our analysis shows that neither the international community nor the governments can buy peace through compensatory means. What matters, by contrast, is the pacifying effect that foreign economic liberalization exerts in the long term.

\section{Conclusion}

One of the still lingering globalization disputes refers to the question of whether or not growing economic ties across nations pacify relations within a society. This article has examined the conflicting hypotheses of the proponents and adversaries of global economic integration through the unifying perspective of what we call the distributional theory of civil conflict. This variant of commercial liberalism maintains that economic openness reduces the risk of internal war, but that the steps toward global economic integration render armed conflict more likely. Our results by and large confirm this double claim. The level of economic trade openness indeed reduces the likelihood of internal conflict, as does the inflow of foreign direct investment. Both variables are also substantively quite important. The suspicion that countries on their way to a more open economy are more susceptible to violence is also supported. Changes in the level of economic openness exert a significant, though substantively minor, positive influence on the risk of conflict, whereas the growth in FDI inflows is not systematically linked to domestic instability.

Although the substantive effect of foreign economic liberalization is comparatively small, compensatory measures by the government or the international financial community do not reduce it. This indicates that attempts to solve social conflicts directly with the checkbook are severely limited. Globalization discontent, our analysis indicates, is a force policy makers and the international community have to consider in their attempts to reform the domestic economy by way of global economic integration.

Our analysis did not lead to conclusive results with regard to the claim by many globalization skeptics that the International Monetary Fund is a major destabilizing force through the austerity packages that it imposes on heavily indebted countries. Attempts to test this claim and some related conjectures suffer under the severe data problems that plague the macroquantitative study of civil conflict (Hegre and Sambianis 2006). We believe that the coming generation of studies that try to uncover the economic motives of intrastate war will more frequently resort to household surveys. This data source has already been successfully linked to macroquantitative examinations in the field of economic growth (Collier and Gunning 1999). A further challenge that besets this area of conflict research is posed by scholars who focus on the ethnic, religious or social identity of those who are affected by economic shocks. At the moment, the materialist and the ideational 
sources of civil unrest are discussed within separate research camps. To overcome this unnatural and unnecessary scholarly division, the future study of civil war has to carefully examine how foreign economic liberalization and other economic factors affect the opportunity cost of warfare and the identification with a particular group. Finally, macroquantiative studies like the research endeavor that we have pursued should be complemented by careful case studies of countries (e.g., Bussmann, Schneider, and Wiesehomeier 2005) that have embarked on a fast liberalization process, such as the cases identified in our outlier analysis, or whose liberalization attempts have been interrupted. The examination of extreme cases helps us in clarifying the conditions under which commercial liberalism is correct, but also those under which it has to be qualified.

\section{References}

Alesina, Alberto, And Allen Drazen. (1991) Why Are Stabilizations Delayed? American Economic Review 81:1170-1188.

Alesina, Alberto, and Roland Wacziarg. (1998) Openness, Country Size and Government. Journal of Public Economics 69:305-321.

Azam, Jean-Paul. (2001) The Redistributive State and Conflict in Africa. Journal of Peace Research 38:429-444.

Beck, Nathaniel, Jonathan N. Katz, and Richard Tucker. (1998) Taking Time Seriously in Binary Time-Series-Cross-Section Analysis. American Journal of Political Science 42:1260-1288.

Bollen, Kenneth A, And Scott T. Jones. (1982) Political Instability and Foreign Direct Investment: The Motor Vehicle Industry, 1948-1965. Social Forces 60:1070-1088.

Bornschier, Volker, Christopher Chase-Dunn, and Richard Rubinson. (1978) Crossnational Evidence of the Effects of Foreign Investment and Aid on Economic Growth and Inequality: A Survey of Findings and a Reanalysis. American Journal of Sociology 84:651-683.

Brennan, Teresa. (2003) Globalization and its Terrors. London: Routledge.

Bussmann, Margit, Indra de Soysa, and John R. Oneal. (2005) The Effect of Globalization on National Income Inequality. Comparative Sociology 4:285-312.

Bussmann, Margit, Harald Scheuthle, and Gerald Schneider. (2003) Die 'Friedensdividende' der Globalisierung: Außenwirtschaftliche Öffnung und innenpolitische Instabilität. Politische Vierteljahresschrift 44:302-324.

Bussmann, Margit, Gerald Schneider, and Nina Wiesehomeier. (2005) Foreign Economic Liberalization and Peace: The Case of Sub-Saharan Africa. European Journal of International Relations $11: 551-579$.

Chan, Steve, and Melanie Mason. (1992) Foreign Direct Investment and Host Country Conditions: Looking From the Other Side Now. International Interactions 17:215-232.

Chus, Amy. (2002) World on Fire: How Exporting Free Market Democracy Breeds Ethnic Hatred and Global Instability. New York: Doubleday.

Collier, Paul, V. L. Elliott, Håvard Hegre, Anke Hoeffler, Marta Reynal-Querol, and Nicholas Sambanis. (2003) Breaking the Conflict Trap. Civil War and Development Policy. Washington: World Bank/Oxford University Press.

Collier, Paul, and Jan Willem Gunning. (1999) The IMF's Role in Structural Adjustment. The Economic Journal 109:F634-F651.

Collier, Paul, And Anke Hoeffler. (1998) On Economic Causes of Civil War. Oxford Economic Papers 50:563-573.

Collier, Paul, and Anke Hoeffler. (2002) Aid, Policy and Peace: Reducing the Risks of Civil Conflict. Defence and Peace Economics 13:435-450.

Collier, Paul, And Anke Hoeffler. (2004) Greed and Grievance in Civil War. Oxford Economic Papers 56:563-595.

Crenshaw, Edward. (1991) Foreign Investment as a Dependent Variable. Social Forces 69:1169-1182.

Deininger, Klaus, and Lyn SQuire. (1996) A New Data Set Measuring Income Inequality. World Bank Economic Review 10:565-591.

De Soysa, Indra. (2002) Paradise Is a Bazaar? Greed, Creed, and Governance in Civil War, 19891999. Journal of Peace Research 39:395-416.

De Soysa, Indra, and John R. Oneal. (1999) Boon or Bane? Reassessing the Productivity of Foreign Direct Investment. American Sociological Review 64:766-782. 
Dollar, David, and Aart Kraay. (2002) Growth Is Good for the Poor. Journal of Economic Growth 73:195-225.

Fearon, James D, and David D. Laitin. (2003) Ethnicity, Insurgency, and Civil War. American Political Science Review 97:75-90.

Fernandez, RaQuel, And Dani Rodrik. (1991) Resistance to Reform: Status Quo Bias in the Presence of Individual-Specific Uncertainty. American Economic Review 81:1146-1155.

Firebaugh, Glenn. (1992) Growth Effects of Foreign and Domestic Investment. American Journal of Sociology 98:105-130.

Fischer, Stanley. (2003) Globalization and its Challenges. American Economic Review 93:1-30.

Garfinkel, Michelle R, Stergios Skaperdas, and Constantinos Syropoulos. (2004) Globalization and Domestic Conflict. Unpublished manuscript, University of California, Irvine, and Florida International University.

Garrett, Geoffrey. (2001) Globalization and Government Spending Around the World. Studies in Comparative International Development 35:3-29.

Gleditsch, Nils Petter, Peter Wallensteen, Mikael Eriksson, Margareta Sollenberg, and Håvard Strand. (2002) Armed Conflict 1946-2001: A New Dataset. Journal of Peace Research 39:615-637.

Grossman, Herschel I. (1991) A General Equilibrium Model of Insurrections. American Economic Review 81:912-921.

HaAvelmo, Trygve. (1954) A Study in the Theory of Economic Evolution. Amsterdam: North-Holland.

Hegre, Håvard, Tanja Ellingsen, Scott Gates, and Nils Petter Gleditsch. (2001) Towards a Democratic Civil Peace? Democracy, Political Change, and Civil War 1816-1992. American Political Science Review 95:17-33.

Hegre, Håvard, Nils Petter Gleditsch, and Ranveig Gissinger. (2003) Globalization and Conflict: Welfare, Distribution, and Political Unrest. In Globalization and Armed Conflict, edited by G. Schneider, K. Barbieri and N. P. Gleditsch. Lanham: Rowman \& Littlefield.

Hegre, Håvard, ANd Nicholas Sambanis. (2006) Sensitivity Analysis of Empirical Results on Civil War Onset. Journal of Conflict Resolution 50:508-535.

Hellman, Joel S. (1998) Winners Take All: The Politics of Partial Reform in Postcommunist Transitions. World Politics 50:203-234.

Heston, Alan, Robert Summers, and Bettina Aten. (2002) Penn World Table, Version 6.1, Center for International Comparisons at the University of Pennsylvania (CICUP). Available at http:// pwt.econ.upenn.edu/downloads/index.htm.

Hirshleifer, Jack. (1989) The Technology of Conflict as an Economic Activity. American Economic Review Papers and Proceedings 81:130-134.

Hsieh, Chang-Tai. (2000) Bargaining Over Reform. European Economic Review 44:1659-1676.

King, Gary, Michael Tomz, and Jason Wittenberg. (2000) Making the Most of Statistical Analyses: Improving Interpretation and Presentation. American Journal of Political Science 44:347-361.

Kobrin, Stephen J. (1982) Managing Political Risk Assessment. Berkeley: University of California Press. Lichbach, Mark. (1995) The Rebel's Dilemma. Ann Arbor: University of Michigan Press.

Lipset, Seymour M. (1959) Some Social Requisites of Democracy: Economic Development and Political Legitimacy. American Political Science Review 53:69-106.

Marshall, Monty G, and Keith Jaggers. (2000) Polity IV Project: Dataset Users Manual. Available at http://www.bsos.umd.edu/cidcm/inscr/polity/index.htm.

Martin, Christian W. (2005) Die doppelte Transformation. Opladen: Westdeutscher Verlag.

Martin, Christian W., and Gerald Schneider. (2007) Pfadabhängigkeit, Konvergenz oder regulativer Wettbewerb: Eine Analyse der außenwirtschaftlichen Öffnung. Politische Vierteljahresschrift Sonderheft 39 (in press).

Miguel, Edward, Shanker Satyanath, and Ernest Sergenti. (2004) Economic Shocks and Civil Conflict: An Instrumental Variables Approach. Journal of Political Economy 112:725-753.

Opp, Karl-Dieter. (1978) Theorie sozialer Krisen: Apathie, Protest und Kollektives Handeln. Hamburg: Hoffman u. Campe.

Quinn, Dennis. (1997) The Correlates of Change in International Financial Regulation. American Political Science Review 91:531-551.

Resnick, AdAm L. (2001) Investors, Turbulence, and Transition: Democratic Transition and Foreign Direct Investment in Nineteen developing Countries. International Interactions 27:381-398.

Ricardo, David. (1921) [1817] On the Principles of Political Economy and Taxation. 3rd edition. London: Murray. 
RoDrik, Dani. (1994) The Rush to Free Trade in the Developing World: Why So Late? Why Now? Will It Last? In Voting for Reform: Democracy, Political Liberalization, and Economic Adjustment, edited by S. Haggard and S. B. Webb. New York: Oxford University Press.

Rodrik, Dani. (1998) Why Do More Open Countries Have Bigger Government. Journal of Political Economy 106:997-1032.

Rogowski, Ronald. (1989) Commerce and Coalitions. How Trade Affects Domestic Political Alignments. Princeton: Princeton University Press.

Rosecrance, Richard. (1986) The Rise of the Trading State - Commerce and Conquest in the Modern World. New York: Basic Books Inc.

Rothgeb, John M. JR. (1990) Investment Dependence and Political Conflict in Third World Countries. Journal of Peace Research 27:255-272.

Rudra, Nita. (2002) Globalization and the Decline of the Welfare State in Less Developed Countries. International Organization 56:411-455.

Rudra, Nita. (2004) Openness, Welfare Spending, and Inequality in the Developing World. International Studies Quarterly 48:683-709.

Russett, Bruce, and John R. Oneal. (2001) Triangulating Peace: Democracy, Interdependence, and International Organizations. New York: W.W. Norton.

Sachs, JefFrey D, AND Andrew Warner. (1995) Economic Reform and the Process of Global Integration. Brookings Papers on Economic Activity 1:1-118.

STiglitz, Joseph E. (2002) Globalization and its Discontents. London: Allen Lane.

Stiglitz, Joseph E. (2004) Capital-Market Liberalization, Globalization, and the IMF. Oxford Review of Economic Policy 20:57-71.

Tomz, Michael, Jason Wittenberg, and Gary King. (2003) CLARIFY: Software for Interpreting and Presenting Statistical Results. Version 2.1, Stanford University, University of Wisconsin, and Harvard University. January 5. Available at http://gking.harvard.edu//stats.shtml.

Tucker, Richard. (1999) BTSCS: A Binary Time-Series-Cross-Section Data Analysis Utility. Version 4.0.4. Cambridge, MA: Harvard University. Available at http://www.fas.harvard.edu/ rtucker/ programs/btscs/btscs.html.

Tullock, Gordon. (1974) The Social Dilemma: The Economics of War and Peace. Blacksburg: Public Choice Center.

Tullock, Gordon. (1980) Rent Seeking as a Negative-Sum Game. In Toward a Theory of the Rent Seeking Society, edited by J. M. Buchanan, R. D. Tollison and G. Tullock. College Station: Texas A\&M University.

UNCTAD. (2002) Foreign direct investment database. Available at http://www.unctad.org.

Walter, Barbara F. (2004) Does Conflict Beget Conflict? Explaining Recurring Civil War. Journal of Peace Research 41:371-388.

Walton, John, and Charles Ragin. (1990) Global and National Sources of Political Protest: Third World Responses to the Debt Crisis. American Sociological Review 55:876-890.

Walton, John, And David Seddon. (1994) Free Markets and Food Riots. Cambrige, MA.: Blackwell.

WeEde, ERICH. (1990) Wirtschaft, Staat and Gesellschaft. Tübingen: Mohr.

World BANK. (2004) World Development Indicators 2004 CD-ROM. Washington, DC: World Bank. 
